\title{
The Candidate Single and Cartelization of Democracy in the Concurrent Local Election 2017
}

\author{
Laode MachdaniAfala, S.IP, M.A', Ahmad Zaki Fadlur Rahman, S.IP, M.A \\ Brawijaya University \\ Malang, Indonesia \\ Email: laode.machdani@gmail.com ${ }^{1}$
}

\begin{abstract}
This paper attempts to explain how cartel politics occur not only in post-electoral but also before electoral. Basically, democracy should be a fair arena for political parties in the competition of choosing a leader, but in contrast, the political parties as political instrument don't compete in electoral. It occurred in the emergence of single candidate massively in the concurrent local election in 2017. By using the political cartel approach in electoral democracy, this paper tries to explain why single candidate appears. Based on the case of the single candidates in some areas, this study tries to draw some conclusions as to why single candidate appeared in the election. First, single candidate arises because the regulation allows enacting only one pair against an empty ballot box. Second, single candidate occurs because there is a shift in party orientation that tends to seek power in government (office-seeking) so the candidates are not ready to stand outside the government. Third, the single candidates arise due to the failure of political parties in the process of regeneration so as not able to produce an alternative leader figure. Fourth, the emergence of the single candidate is also due to the strengthening of the power network of the incumbent in optimizing the state's resource for the winning of the election. Thus, the emergence of single candidate leads to the shaping of the cartelization of democracy in the concurrent local election in 2017.
\end{abstract}

Keywords: Single candidate, Cartelization, Democracy, Local Election.

\section{INTRODUCTION}

Elections are one of the mechanisms to produce democratic political leaderships. It can be occurred through democratic election, in which there is a competition among potential leaders. The hope is that the competition will appear qualified leaders through ideas and programs. In addition, with competition, the people (voters) are not co-opted in a predetermined selection of candidate leaders through an agreement among party or candidate elites. In other words, the implementation of competitive elections will certainly encourage consolidation democracy as well.

However, the emergence of a single candidate in the concurrent local electoral stage in 2015 and 2017 becomes an irony in a democratic country. As defined by Joseph Schumpeter (in Huntington, 1991: 6) that democracy is understood as institutional arrangements to achieve political decisions whereby individuals, through the struggle for the voting of the electorate, acquire the power to make decisions (see Mas'oed, 1994:15). Likewise, Robert Dahl (1973), explains that the implementation of democracy can be realized with the presence of competition and participation effectively - "Polyarchy". The notions clearly state that the presence of competition is a prerequisite for the presence of a democratic country. While the appearance of this single candidate implicitly signifies the absence of competition in elections, especially in the local election.

At least, in the two rounds of 2015 and 2017 concurrent local elections have been colored by the phenomenon of the emergence of a single candidate. Recorded, in the elections simultaneously in 2015, there were 11 electoral districts that had a single candidate. However, after the KPU gave extra time for registration, the remaining 3 districts still had a single candidate, namely Blitar, Tasikmalaya, and North Middle East Regencies. The rest was postponed its implementation until 2017. While in 2017 concurrent local election, there are 9 election districts that have a single candidate. These districts are Tebing Tinggi, TulangBawang Barat, Pati, Landak, Buton, Central Maluku, Jayapura, Tambrauw, and Sorong (KPU RI 2017). Compared to the first stage of concurrent local election, this second stage shows an increasing number of single candidates appearing dominated by incumbent candidates.

In fact, one of the expectations of this concurrent local election is the increasing number of competition due to the merging of several elections concurrently. Likewise, the level of community participation is expected to increase. In general, the design of concurrent local election held is actually an effort to 
strengthen the presidential system so that the elected executive officers come from the party or a combination of the majority party (Bakti, 2015). The goal is that concurrent local election impacts the emergence of a coattail effect, namely a pattern whereby when a party or party coalition wins the election, the president and vice president also come from the same party (Madariaga\&Ozen, 2015). In addition, the concurrent local election is believed to have an effect on the presence of political efficacy, which gives voters greater freedom to make intelligent choices. Therefore, the idea of concurrent election is not really a matter of time, but how legislative and executive elections are carried out concurrently, forcing the party to build an ideological coalition before the presidential and vice presidential election. But, the logic of concurrent election ideas is captured by the Commission General Election (KPU) only as a strategy in organizing election effectively and efficiently, including in conducting the election of regional heads (Budiman, 2015). One of the impacts is the emergence of single candidate after enacted concurrent local election in 2015 and 2017.

In the study of election, only a few people have examined why a single candidate appears in the concurrent local election. In general, the debate in the study of single candidates is more concerned with whether election with single candidates or not is democratic. In his study of a single election in Blitar, Dhesinta (2016) argues that election with a single candidate is considered democratic because the community has participated in electing the regional head, and is free to vote for the candidate, although the choice is in between agreeing and disagreeing with a single candidate. In similar vein, in a study conducted by Hardiyanto, Suharso and Budiharto (2016) on a single candidate in the period of 2015, assumed that the election with a single candidate is still considered democratic, it is because the essence of democracy showed by the involvement of the public in the holding of election. Meanwhile, the study written by Rumesten (2016), argues that the concurrent local election with one candidate has injured the growing democracy in Indonesia. As Dahl (1973) argues that in democracy, at least, there are elements of competition and participation. Clearly, in the concurrent local election with a single candidate, there is no competition in it so it can be said that the election is less democratic. Therefore, this paper tries to explain why a single candidate appeared in the concurrent local election of Indonesia with using the cartel politics and procedural democratic of Robert Dahl as approach.

\section{RESEARCH METHOD}

To understand the emergence of single candidates in the concurrent local election of 2017, this study uses qualitative-explanatory research methods. The data used in this study is secondary data obtained from various literatures. The data analysis in this study uses the political approach of the cartel and the democratic concept of Robert Dahl. In doing so, the data obtained are categorized, and synthesized according to their relevance. The study is analyzed with two main objectives; firstly, to understand how a single candidate appears. Secondly, to track the consequences of the trend of single candidate for the development of Indonesia democracy in future.

\section{RESULT AND DISCUSSION}

\section{A. Cartel Politics and Electoral Democracy}

The democratic state of Robert Dahl is characterized by a continuous government responsiveness to the preferences of its citizens by considering the political equality. For that, the democratic order can be characterized by the existence of two dimensions, namely; first, how high the level of contestation, competition or possible opposition; and second, how many citizens have the opportunity to participate in the political competition. In other words, good democracy when the political order has a high participation and competition, called by as Polyarchy.

Procedurally, Dahl's idea of democracy is almost identical to Schumpeter's idea of electoral democracy. This idea is also known as the minimalist or Schumpeterian democracy which is the most effective choice of democratic model in managing the struggle for power struggle (White, 2016). Democracy model based on election or contestation is actually one of the paradigms in understanding democracy based on rational choice in managing power conflict. This democratic model assumes that all individuals are free to become leaders, if they are elected through a mechanism called elections. As a consequence, in conducting democracy this model requires the existence of representative groups that have a common goal or ideology or often known as a political party. Thus, political parties become instruments of competition in the elections to elect leaders. 
As an instrument in electoral democracy, political parties should compete with each other for the positions of power in government through election. Then, according to Mainwairing (1993), the pattern of party competition does not only stop at the time of election, but also postelection so that the government model is created in which there are checks and balances as in the presidential system which requires two groups between government parties and nongovernment parties. Non-government parties function to control the running of the government, at the same time looking for lack of government parties as power for the next election. However, in party systems that have many parties or multiparty, then the coalition becomes inevitable. Nevertheless, the coalition remains based on ideological similarity among coalition party members so as to maintain a competitive party system.

In the context of Indonesia, the party system is very competitive during the election, but there is cooperation or coalition after the election (Ambardi, 2009). Inter-party cooperation that no longer considers the ideological aspect and tendency to take part in government position, according to Ambardi (2009) is a cartel party system. It becomes the opposite of the previous competitive party system. In the competitive party system, the party acts as an instrument in seizing public position as well as representing the ideology of social groups. While in the cartel party system, the competition is changed to secure the interest each other so that there occurs a pattern of cooperation between parties that no longer stand on ideological representation, but for the interests of securing each other. Thus, cartel politics in the context of electoral democracy is a collaborative effort and avoids competition between parties in order to gain short-term pragmatic advantage in securing power within government. Democracy is ultimately held hostage in the interests of oligarchs or elites.

\section{B. Single Candidate; Pathway to Cartelization of Democracy}

\section{A. Supporting Regulation}

Facing the implementation of the concurrent local election in 2015, the government enacted a law no. 8 of 2015 which regulates the implementation of concurrent local election of Governor, Mayor and Regent. The first concurrent local election was held on 9 December 2015, which was attended by 9 provinces, 36 cities and 224 contested districts. However, out of a total of 269 such areas, there are a few issues, namely the emergence of single candidates in 11 electoral districts that are not regulated in Law no. 8 of 2015. According to IzaRumesten (2016), the regulation has not fulfilled the philosophical and juridical aspect adequately so that it is necessary to change the rule. The absence of legal regulation on the phenomenon of single candidate has made the presence of legal vacuum associated with the implementation of concurrent local election. Then, this single candidate phenomenon is responded by Indonesia Constitutional Court (MahkamahKonstitusi) by issuing Decision of MK No.100/PUU-XIII/2015 that regulates the existence of single candidate. In the verdict, if there is a single candidate, the election organizer extends the registration schedule for three days. If up to three days there is no registration, then the pair of candidates is set as one candidate pair to contest against empty box.

As a revision of Law no. 8 year 2015, in 2016, the government then issued Law no. 10 of 2016 which regulates the existence of a single candidate. Article of $54 \mathrm{C}$ and $54 \mathrm{D}$ Law no. 10 of 2016 clearly explains the mechanism of the existence of a single candidate. If up to the deadline for registration renewal no candidates register, a candidate pair will be opposed to an empty box. A candidate pair is declared victorious when earned more than $50 \%$ of the vote. Otherwise, the empty box wins and the election will be postponed until the next electoral election.

The presence of this rule indirectly also opens opportunities for the presence of a single candidate at the next election. This is proved in the 2017 concurrent local election in which of the total of 101 electoral districts there are 9 electoral districts with single candidates. This number is more than the first round of 2015, leaving only 3 single candidates. Thus, the presence of Law no. 10 year 2016 provides a political opportunity for political parties to determine who the leaders in a region.

\section{B. Party Orientation to Office-Seeking}

The absence of candidate pairs competing in the election is one indication of the weak institutionalization of political parties. A political party that is an intermediary actor between a society and a state should have a political orientation to the welfare of its constituents. The orientation of political party can be seen in an 
ideological platform that becomes the direction and orientation of the struggle. However, so far, many political parties tend to veer away from their ideological platform. It can be seen in party coalitions with different ideology lines that shows a pragmatic orientation of party change both national and local levels. In table 1.1, it appears that almost all existing political parties supporting single candidates have different ideological platforms, so clearly, the orientation of political parties leads to office-seeking, being part of a regime of power or a winner.

In general, competitive behavior of political parties according to Strom (1990) there are three, namely; vote-seeking, policy-seeking and office-seeking. In this case, political parties not only seek to seize power but also fulfill the collective interests of their constituents. Ideally, democratic political parties are characterized by the idea that the political process encourages the transformation of people's preferences through the means of party mediation (responsiveness) into policy choices and government action (accountability). However, in the case of the emergence of a single candidate, the behavior of political parties is only oriented to office-seeking (seizing power), by not presenting competition between political parties. Changes in orientation of this political party, of course closely related to the weak institutionalization of political parties. Randall and Svasand (2002) explain at least four important variables in institutionalization of political parties, namely systemness, value infusion, decisional autonomy, and reification. These four variables will indirectly strengthen the position and direction of political party orientation clearly as a political organization. Well-instituted political parties will certainly encourage competitive elections and of course have a consistent political orientation as well.

\section{The Failure of Party Recruitment}

One of the reasons for the emergence of a single candidate is the failure of the party to perform its functions. As a political organization, political parties have a role to bridge the interests of the people and the state. This role is run by performing functions as intermediate actors. According Caton (2007: 7) in the democracy, there are 4 central functions of political parties, namely; first, the articulation of interests, it is to develop consistent programs and government policies. Second, the function of interest aggregation, it picks up the demands of society and wraps it up. Third, recruitment, it is to selects and trains people for positions in the executive and legislative. Fourth, the function are supervise and control the government.

Related with the appearance of a single candidate, the function of political parties in recruitment is not working well. Political parties do not seriously build the process of cadre so as not to give birth to a figure or a qualified leader who comes from his party. Many of the candidates in the elections did not come from the process of reconciliation in their political parties, but from outside political parties. This became one of the failures of political parties which resulted in the absence of the right figure to be proposed as a strong and qualified candidate. Political parties in preparing candidates tend to unplanned so difficult to determine the right candidate. The lack of political party cadres in the nominating makes political parties dependent on other figures outside the party. As a result, the ideology of the party is mortgaged and the election becomes uncompetitive

\section{Strengthening of Power Networking of Incumbent}

Another factor that resulted in the presence of a single candidate in the concurrent local election is the strength of the candidate incumbent figure. In general, an incumbent candidate must have had a large power base compared to a new candidate. The incumbent candidate in his tenure has invested and built his network of power in both the bureaucracy, the people, the businessmen, and the national elite. This is done in an attempt to prepare himself in continuing his power relay. Of course, this effort has been done long before other candidates run. As a result, other candidates retreat for run slowly. Conversely, for political parties, incumbent candidates at the local level provide the advantage to maximize strength in facing presidential election 2019.

In addition, the incumbent candidates have the ability to buy political party support so that none of the parties nominate candidates. In 2017 concurrent local election, there are at least 8 singgle candidates who are incumbents and only one candidate is not incumbent, that is Landak Regency. In spite of non-incumbent, Regent Landak candidate, namely Karolina Margret Natasa has huge networking power. She is a member of the House of Representatives of the PDIP party and her pair is the former Regent of Landak. Also, Karoline is the daughter of the West Kalimantan governor, Cornelis, who is considered most influential in the Landak 
bureaucracy. Karoline is a member of the House of Representatives two periods (2009 and 2014) with the second largest number of votes throughout Indonesia. Although Karoline is not a candidate incumbent, but vice regent is incumbent so that this candidate pair is basically a candidate incumbent. His power network has long been built into his father's power network.

In another highlight, in Table 1.1, the power of these candidate incumbent can be seen from the amount of support of the political party. West TulangBawang Regency supported by 10 political parties and other districts supported by mostly 8 and 7 political parties. It becomes one proof of the strength of the power networking of incumbent candidates. However, the support of political parties will be indebted and the absence of other forces outside the party potentially leads to the strengthening of cartel politics at the local level. With regard this situation, Slater (2004), called Indonesia's democracy often trapped in cartel politics - collusive democracy.

Table 1.1

List of Prospective Single Candidate in Concurrent Local Election 2017

\begin{tabular}{|c|c|c|c|c|}
\hline No & Districts & Candidate & Status & Supporting Parties \\
\hline 1. & \begin{tabular}{|ll}
$\begin{array}{l}\text { Tebing } \\
\text { City }\end{array}$ & Tinggi \\
\end{tabular} & $\begin{array}{l}\text { Ir. H. Umar Zunaidi Hasibuan, } \\
\text { M.M. dan Ir. H. Oki Doni Siregar }\end{array}$ & Incumbent & $\begin{array}{l}\text { Nasdem, Demokrat, } \\
\text { Hanura, Gerindra, PKB, } \\
\text { Golkar, PDIP, PPP }\end{array}$ \\
\hline 2. & \begin{tabular}{|l|} 
Kabupaten \\
Tulang Bawang \\
Barat Regency
\end{tabular} & $\begin{array}{l}\text { Umar Ahmad, SP dan Fauzi } \\
\text { Hasan, S.E, M.M }\end{array}$ & Incumbent & $\begin{array}{l}\text { PKS, Demokrat, PPP, PDIP, } \\
\text { Gerindra, Golkar, PAN, } \\
\text { PKB, Hanura, Nasdem }\end{array}$ \\
\hline 3. & Pati Regency & $\begin{array}{l}\text { H. HARYANTO, SH, MM, M.Si } \\
\text { dan H. SAIFUL ARIFIN }\end{array}$ & Incumbent & $\begin{array}{l}\text { PDIP, Gerindra, PKS, PKB, } \\
\text { Demokrat, Golkar, Hanura, } \\
\text { PPP }\end{array}$ \\
\hline 4. & \begin{tabular}{|l} 
Landak \\
Regency
\end{tabular} & $\begin{array}{l}\text { dr. Karolin Margret Natasa dan } \\
\text { Herculanus Heriadi, SE }\end{array}$ & $\begin{array}{c}\text { Non- } \\
\text { Incumbent }\end{array}$ & $\begin{array}{l}\text { PDIP, Demokrat, PKB, } \\
\text { Golkar, Hanura, Nasdem, } \\
\text { Gerindra, PAN }\end{array}$ \\
\hline 5. & Buton Regency & $\begin{array}{l}\text { SAMSU UMAR ABDUL } \\
\text { SAMIUN, SH dan Drs. LA } \\
\text { BAKRY, M.Si }\end{array}$ & Incumbent & $\begin{array}{l}\text { PKB, PKS, Nasdem, PAN, } \\
\text { Demokrat, Golkar, PBB }\end{array}$ \\
\hline 6. & \begin{tabular}{|l|} 
Maluku Tengah \\
Regency
\end{tabular} & \begin{tabular}{|l|} 
TUASIKAL ABUA, SH dan \\
MARTLATU L. LELEURY, SE
\end{tabular} & Incumbent & $\begin{array}{l}\text { Gerindra, Golkar, Hanura, } \\
\text { Demokrat, Nasdem, PAN, } \\
\text { PBB, PDIP }\end{array}$ \\
\hline 7. & Jayapura City & $\begin{array}{l}\text { Dr. Drs. Benhur Tomi Mano, } \\
\text { M.M. dan Ir. H. Rustan Saru, } \\
\text { M.M. }\end{array}$ & Incumbent & $\begin{array}{l}\text { PKB, Hanura, PAN, } \\
\text { Nasdem, Golkar, PDIP, } \\
\text { Gerindra }\end{array}$ \\
\hline 8. & $\begin{array}{l}\text { Tambrauw } \\
\text { Regency }\end{array}$ & $\begin{array}{l}\text { GABRIEL ASEM, SE, M.Si dan } \\
\text { MESAK METUSALA YEKWAM, } \\
\text { SH }\end{array}$ & Incumbent & $\begin{array}{l}\text { Nasdem, PDIP, Golkar, } \\
\text { Demokrat, Gerindra, PKS, } \\
\text { PKB, Hanura }\end{array}$ \\
\hline 9. & Sorong City & $\begin{array}{l}\text { Drs. Ec. Lamberthus Jitmau, } \\
\text { MM dan dr. Hj. Pahima } \\
\text { Iskandar }\end{array}$ & Incumbent & $\begin{array}{l}\text { Golkar, Demokrat, PDIP, } \\
\text { PAN, Nasdem, Gerindra, } \\
\text { Hanura, PKB }\end{array}$ \\
\hline
\end{tabular}

Source: KPU RI

\section{Inclusive Hegemony: Participation without Competition}

Based on the results of concurrent local election in 2017 the national participation rate increased by 74, 20\%. Compared to the 2015 elections, the participation rate only reached $70 \%$. Nevertheless, both are lower than the KPU's desired target of 77, 50\% in national rate. For nine regions with single candidates the average participation rate is above $70 \%$, there is only one region that its participation rate is below $70 \%$, that is Buton regency with $55,08 \%$. While the participation rate is above $77,50 \%$ of the national standard there are five regions with single candidates, namely TulangBawang district (96, 75\%), Landak district $(96,72 \%)$, Jayapura $(84,34 \%)$, and Sorong $(78,09 \%)$. This high level of participation indirectly shows the enthusiasm of the community to get involved in exercising their voting rights. In democracy, this participation becomes an important indicator to measure the success rate of an election. The below table 1.2 shows the level of participation.

From the phenomenon of high participation in elections simultaneously with single candidates, does it lead to effective participation that fosters the quality of democracy? In the view of Robert Dahl (1973), the high participation in the election area with a single candidate leads to an indication of inclusive hegemony, namely the presence of participation that is not accompanied by high contestation or competition between candidates or political parties. For Dahl (1973: 7), the high level of participation is due to the emergence of great popularity, from candidates or competing political parties. However, popularity is not enough to explain the inclusive hegemony and the appearance of a single candidate. Of the nine single candidates in the concurrent local election of 2017, only Landak regency whose candidate is not an incumbent. That can be indicated as Fyodor Krasheninnikov, that a single candidate appears precisely because of a sabotage or boycott to block competition or competition. Therefore, in the case of a single candidate, a high level of participation occurs because voters are trapped in the absence of other options. 


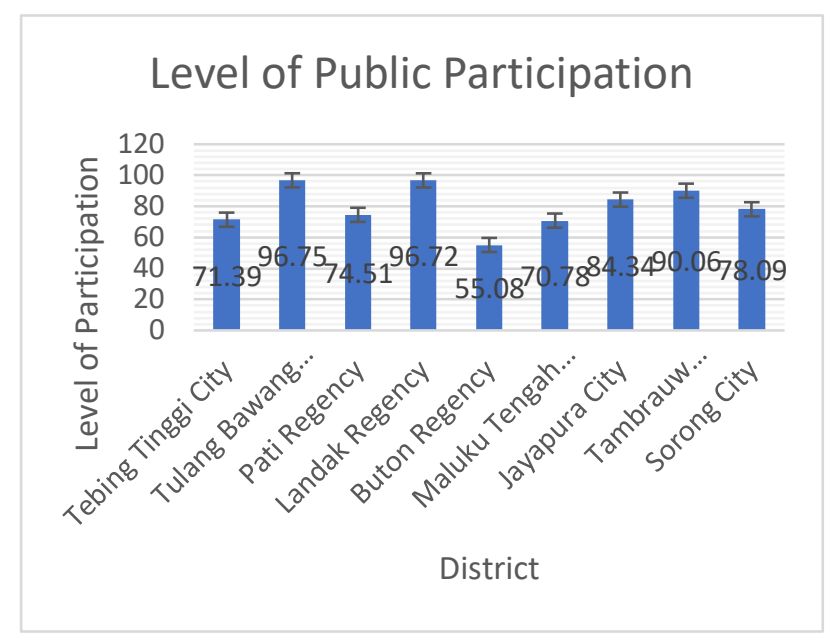

Table 1.2

Level of Public Participation in Concurrent Local Election of 2017 in the District of Single candidate

Source: Commission General Election of Indonesia Republic (2017)

\section{CONCLUSION}

The emergence of single candidate in the concurrent local election both in 2015 and 2017 has potentially led to the cartelization of Indonesian democracy. The lack of competition among political parties in carrying their candidates has led to a new space of cartel politics, that is, cartels in the electoral arena at the local level. This portrait encompasses previous studies, where cartel politics generally takes place in the government (Katz and Mair, 1995) and in parliament (KuskridoAmbardi, 2009). In the concept of democracy of Robert Dahl, the emergence of this single candidate leads to inclusive hegemony, i.e. when democratic space is opened so that people can participate in politics but not accompanied by the presence of competition or contestation. Thus, a high level of participation is precisely the result of an inclusive hegemony of a particular group (cartel group). It is caused by the nonworking of political party machinery as a means of cadre recruitment affected to the change of party orientation to office-seeking. This is the main cause of the emergence of a single candidate. In this point, concurrent election appears to be procedural, without substance to strengthen democratic development. Thus, in the context of the concurrent local election, the emergence of a single candidate transforms the democratic pendulum further away from deepening democracy and democracy appears to be countered in the interests of cartel groups the "cartelization of democracy"

\section{ACKNOWLEDGMENT}

This paper would not have been possible without discussion and suggestion of some friends. We are especially indebted to some colleges in Government Department of Brawijaya University who have given much insight about this topic.

\section{REFERENCES}

Ambardi, K. (2009). Mengungkap Politik Kartel: studi tentang sistem kepartaian di Indonesia era reformasi. Kepustakaan Populer Gramedia bekerjasama dengan Lembaga Survei Indonesia

Dahl, R. A. (1973). Polyarchy: Participation and opposition. Yale University Press.

Dhesinta, Wafia Silvi, 2016. Calon Tunggal Dalam Pemilihan Umum Kepala Daerah dan Konsep Demokrasi, dalam jurnal Cita Hukum.Fakultas Syariah dan Hukum UIN Jakarta Vol.4 No.1 Juni 2016.

Hardiyanto, H., Suharso, S., \& Budiharto, B. (2016). PEMILIHAN UMUM KEPALA DAERAH PERIODE 2015/2020 (STUDI POLITIK HUKUM CALON TUNGGAL). Varia Justicia, 12(2), 204-221.

http://www.kpud-bantulkab.go.id/berita/405prof-ikrar-nusa-bakti-urgensi-pemiluserentak.

http://www.kpu.go.id/index.php/post/read/20 15/3829/Arief-Tujuan-Pilkada-SerentakUntuk-Terciptanya-Efektivitas-danEfisiensi-Anggaran

http://intersectionproject.eu//article/politics/si ngle-candidate-elections-boycott-orsabotage

J. Clerk Maxwell, A Treatise on Electricity and Magnetism, 3rd ed., vol. 2. Oxford: Clarendon, 1892, pp.68-73.

Katz, R. S., \& Crotty, W. J. (Eds.). (2006). Handbook of party politics. Sage.

Katz, R. S., \& Mair, P. (1995). Changing models of party organization and party democracy: 
the emergence of the cartel party. Party politics, 1(1), 5-28. Eason, B. Noble, and I.N. Sneddon, "On certain integrals of Lipschitz-Hankel type involving products of Bessel functions," Phil. Trans. Roy. Soc. London, vol. A247, pp. 529-551, April 1955. (references)

Mainwaring, S. (1993). Presidentialism, multipartism, and democracy: The difficult combination. Comparative political studies, 26(2), 198-228

Madariaga, A. G., \& Ozen, H. E. (2015). Looking for two-sided coattail effects: Integrated parties and multilevel elections in the US. Electoral Studies, 40, 66-75

Mas'ud, M. (1994). Negara, kapital, dan demokrasi. Pustaka pelajar.

Naskah Kademik rancangan UU tentang Peneyelnggaraan Pemilihan Umum oleh Kementerian Dalam Negeri, hlm 43

Pamungkas, S., \& Parlindungan, U. (2011). Partai politik: teori dan praktik di Indonesia. Institute for Democracy and Welfarism, hlm 20.

Randall, V., \& Svåsand, L. (2002). Party institutionalization in new democracies. Party politics, 8(1), 5-29.

Rumesten, I. Fenomena Calon Tunggal dalam Pesta Demokrasi. Jurnal Konstitusi, 13(1), 063-082.

Surbakti, R., Isra, S., Ambardi, K., Harjanto, N., Supriyanto, D., IP, S., \& Nurhasim, M. (1993). PEMILU NASIONAL SERENTAK 2019. Comparative Political Studies, 26(2), 198-228.

Slater, D. (2004). Indonesia's accountability trap: Party cartels and presidential power after democratic transition. Indonesia, (78), 61-92

Strom, K. (1990). A behavioral theory of competitive political parties. American journal of political science, 565-598 